\title{
KAMPANYE DAMAI, KOMITMEN ATAU JARGON? \\ DITINJAU DARI TEORI PRINSIP REFLEKSI HATI NURANI \\ MANUSIA
}

Dr. A. W. Dewantara, S.S., M.Hum

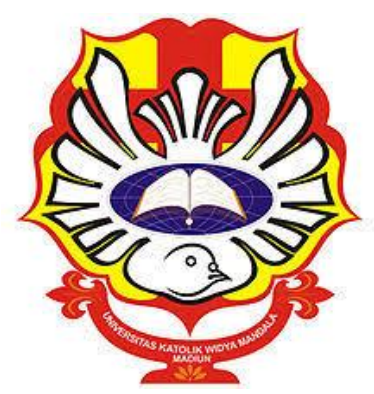

Disusun oleh :

Vadelia Rahmanda Kunsidarta (51416072)

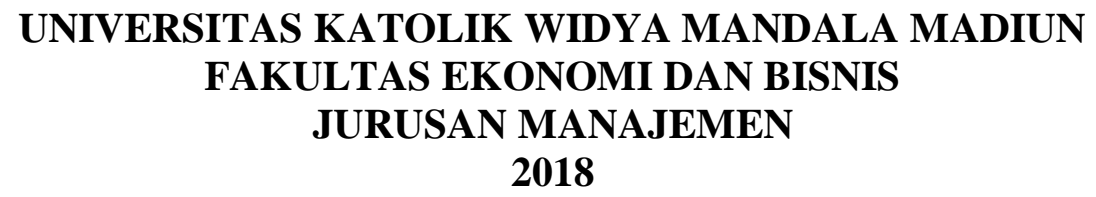




\begin{abstract}
ABSTRAKSI
Pesta demokrasi memang tidak setiap tahun terjadi, namun pesta demokrasi ini merupakan perhelatan besar yang melibatkan banyak pihak untuk terjun di dalamnya. Tahun 2019 menjadi tahun yang sangat menegangkan bagi bangsa Indonesia karena akan memilih presiden dan wakil presiden yang tentunya juga akan menentukan masa depan bangsa Indonesia selanjutnya. Para petinggi-petinggi negri yang menjadi juru bicara masing-masing pasangan calon presiden dan wakil presiden berlomba-lomba untuk menggaskan dan mendeklarasikan apa yang menurut mereka harus di sampaikan agar masyarakat Indonesia sadar mana yang lebih pantas menjadi pemimpin negara Indonesia untuk kedepannya. Sebagai negara yang besar dengan beraneka ragam suku dan budaya Indonesia harus menjadi negara yang tetap utuh, bersatu dan saling menghormati satu sama lain.
\end{abstract}

Keywords: demokrasi, memilih presiden dan wakil presiden, bersatu 


\section{BAB 1}

\section{LATAR BELAKANG}

Hati nurani secara fenomenologis, dari realitas bahwa manusia selalu melakukan pertimbangan-pertimbangan dalam hidupnya. Melakukan pertimbangan artinya manusia memiliki semacam gradasi nilai-nilai yang menjadi fundamen untuk menegaskan pilihanpilihan dan melakukan keputusan. Hati nurani berarti hati manusia memiliki pengetahuan, dan soal pengetahuan tak pernah merupakaan soal hati melainkan soal akal budi (rasio).

Kasus yang saya bahas disini adalah kasus tentang kampanye damai, komitmen atau jargon?. Di tahun ini Indonesia sedang ramai akan pesta demokrasi, dan banyak masyarakat yang ikut serta menjadi bagian untuk menjadi pemimpin rakyat. Dari golongan atas sampai menengah, pekerja maupun pebisnis,tua maupun muda semua berlomba-lomba menjadi yang terbaik untuk dapat mengambil hati masyarakat. Di masa ini banyak para calon lesgislatif maupun calon presiden menjanjikan sesuatu kesejahteraan bagi masyarakat dari hal pekerjaan, ekonomi, pendidikan maupun perkembangan Indonesia untuk menjadi bangsa dan negara yang aman damai dan tentram.

Namun di masa ini adalah masa yang sangat sensitif dimana suhu politik semakin panas, dan banyak para anggota legislatif dan calon presiden saling berkampanye untuk menampilkan yang terbaik. Dan di masa ini banyak sebagian orang yang memanfaatkan suasana agar mendapatkan simpatik yang tinggi di hati masyaraat, mulai banyaknya para profokator-profokator yang mengkeruhkan suasana agar kubu satu dengan satunya saling menjelek-jelakkan dan saling melemahkan satu sama lain. Dengan adanya suasana seperti ini membuat suasana di Indonesia menjadi sangat panas dan mencengkram, membuat masyarakat juga ada sebagain yang terprofokasi dan ada sebagian masyarakat yang berfikir tenang berfikirdengan kecerdasan untuk dapat memilih yang terbaik bagi masyarakat Indonesia. Karena para petinggi-petinggi ini merupakan harapan rakyat, wakit rakyat yang memperjuangkan rakyat untuk terus sejahtera, aman, damai dan tentram. 


\section{BAB II}

\section{A. LANDASAN TEORI}

Hati nurani manusia merupakan suara Tuhan, banyak pertimbngan yang diberikan untuk mengantar manusia kepada Allah. Jadi dapat disimpulkan bahwa hati nurani tidak berurusan dengan benar atau salah secara etis namun langsng menunjuk kepada relasi manusia dengan Allah dalam cara-cara yang tidak bisa reduksi dalam agama formal.

Hati nurani disebut juga "synderesis" yang berkaitan dengan langsung dengan kesadaran hati. Hati nurani seperti kapasitas/daya/kekuatan yang pertimbangan dan pemeriksaannya mengatasi hukum, fenomena baik ataupun buruk sebagaimana di gagas oleh publik kebanyakan mengatasi larangan ataupun perintah dalam peraturan-peraturan yang di miliki dalam hidup manusia. Hati nurani dalam pengertian ini merupakan hati manusia yang membimbing hati manusia. Sehingga disini kita dapat menggaris bawahi bahwa apapun yang dilakukan oleh manusia dari perkataan,perbuatan ataupun tingkah laku semua asalnya dari hati nurani. Hati nurani tumbuh karena adanya suatu kesadaran batin yang ada dalam hati manusia.

Manusia bisa bersikap tidak baik karena dalam hatinya terdorong sikap yang mewujudkan dirinya untuk melakukan hal yang tidak baik, bahkan apabila kita melihat perilaku seseorang yang tidak baik kita akan merasa geram ataupun tidak suka dengan segala tingkah yang di lakukan. Inilah dorongan hati nurani dari orang yang berbuat ataupun orang yang melihat mempunyai umpan balik sendiri-sendiri. Ada banyak macam hati nurani manusia yang di dalam setiap pribadi hati berbeda-beda, hati nurani tumpul ini kurang pekapeka terhadap nilai-niolai kebenaran sehingga lama-lama kesetiaannya pada nurani menjadi tumpul. Yang menjadi ketumpulan materialisme, sekularisme, konsumerisme, hedonisme. Bisa menjadi penyebab menusia kerap menomorsatukan hal-hal tersebut sehingga pelanpelan kebenaran dan kesejatian hidup tersisih. Dalam hati nurani skupel juga terdapat perasaan untuk tidak melakukan dosa, dan yang terakhir ada hati nurani tajam yang semacam ini terlatih dengan cepat membedakan makna yang baik dan mana yang baru. Dari macam hati nurani dalam diri seseorang hanya terdapat satu hati nurani yang melekat pada diri seseorang. Hati nurani yang tumbuh dalam diri seseorang ada karena dorongan hati untuk melakukan suatu sikap dan tindakan yang menurut seseorang itu sudah benar dan akan berdampak baik untuk orang yang mendengar, melihat dan memperhatikan diri seseorang itu. Karena hati nuranu timbul karena ada akal budi yang melekat dalam hidupnya untuk memperkuat ilmu pengetahuan yang lebih mendalam dengan berdasarkan alasan atau pertimbangan budi dengan seimbang. 


\section{B. PEMBAHASAN}

Di tahun ini Indonesia akan merayakan pesta demokrasi, dari pemilihan presiden dan wakil presiden sampai pemilihan legislatif. Dari kalangan masyarakat ikut serta dalam menudukung dan mendeklarasikan pilihannya, karena suhu politik di Indonesia saat ini sedang tinggi dan tidak banyak orang yang berfikir cerdas dan mawas membuat kebanyakan orang terbawa suasana politik yang berdampak tidak baik juga bagi masyarakat Indonesia. Karena setiap pilihan masyarakat berbeda yang di unggulkannya juga berbeda sehinggi antar masyarakat saling mencemooh, menfitnah, menghina demi mengunggulkan pilihannya.

Karena tahun 2019 Indonesia memilih presiden dan wakil presiden yang menentukan perkembangan bangsa Indonesia selanjutnya untuk lebih maju, berkembang danmasyarakatnya lebih sejahtera, aman dan damai. Dan pesta demokrasi 2019 sudah dimulai, calon presiden dan wakil presiden sudah di tentukan yaitu bapak Joko Widodo atau Jokowi dan bapak Prabowo Subianto, dan masa kampanye pemilu presiden dan wakilpresiden sudah di mulai, deklarasi kampanye damai menjadi awal kedua kandidat mendeklarsikan gagasannya untuk merebut hati pemilihnya. Akan tetapi baru saja di mulai saling sindir yang terjadi antara kubu bapak Jokowi dan bapak prabowo, kedua kubu saling beradu data dan kecerdasan apa yang terjadi di Indonesia dan kedepannya bangsa Indonesia ini akan seperti apa. Dari saling sindir dan saling mencemooh antara kubu Jokowi dan kubu Prabowo membuat setiap lapisan masyarakat kawatir akan bagaimana kedepannya Indonesia akan terus maju dan berkembang apabila para petinggi-petinggi Negri ini tidak saling berkomunikasi dengan baik untuk menyukseskan pesta demokrasi ini.

Semakin panasnya suhu politik pada pemilu tahun 2019 membuat para profokatorprofokator semakin marak untuk memecah belah persatuan bangsa Indonesia ini dengan cara yang tidak layak contohnya saja dari kalangan airtis Ahmad Dhani yang terbelit kasus ujaran kebencian yang membuat semakin panasnya sushu politik yang ada di Indonesia sekarang ini, seolah setiap kubu masing-masing saling menjatuhkan dan tidak menggalak pemilu yang damai, tentram dan sejahtera agar masyarakat juga dapat memilih dengan tepat dan cerdas untuk masa depan bangsa Indonesia. Karena antara timses Jokowi dan timses Prabowo saling adu gagasan yang membuat semakin memanasnya kedua kubu dengan mendeklarasikan apa yang menurut mereka benar dengan peristiwa dan kejadian yang terjadi di Indonesia yang menjadi bahan pembicaraan. Saling menjatuhkan, menggulkan pilihannya masing-masing dan saling mencari kesalahan anatara kubu Jokowi dan Kubu Prabowo.

Inilah bangsa Indonesia dengan segala permasalahannya, dimana para petinggipetinggi negara ingin berlom-lomba mendapat tempat untuk kepentingan pribadi bukan untuk 
kepentingan masyarakat Indonesia. Baru-baru ini ada beberapa stasiun televisi yang menyiarkan perdebatan antara timses Jokowi dan timses Prabowo, mereka saling adu pendapat yang menurut mereka benar. Sebenarnya saling menjatuhkan satu sama lain itu tidak baik karena dapat mendorong masyarakat luas untuk tidak berkampanye dengan baik juga, karena perdebatan itu di siarkan secara langsung di televisi sehingga masyarakat luas mengetahui apa yang di bahas dan apa yang di permasalahkan antara dua kubu. Tidak semua lapisan masyarakat dapat menerimanya dengan cerdas dan mawas, sehingga perdebatan itu dapat berdampaktidak baik juga bagi masyarakat. Masyarakat merasa di ombang-ambingkan oleh suasana yang tidak sehat suasana negatif yang membuat gaduh masyarakat. Sampai ada berita yang menyatakan ada suami istri yang bertengkar yang berujung pembunuhan karena disebabkan pilihan yang berbeda. Dari sejumlah peristiwa ini betapa kita sadar masih banyak masyarakat Indonesia yang tidak dapat meyerap informasi dengan baik. Dalam situasi seperti ini seharusnya petinggi-petinggi negri atau wakil rakyat harus menjadi contoh yang baik bagi msyarakat untuk tetap berfikir cerdas dan mawas untuk ikut serta dalam pesta demokrasi dengan aman dan damai. Dalam perdebatan di televisi timses Jokowi yang berpendapat bahwa timses Prabowo sangat pintar sekali mengatur skenario untuk dapat menggoyahkan bangsa Indonesia dari kasus penganiayaan ibu Ratna dan kasus-kasus lainnya. Dan timses Prabowo yang berpendapat tidak etisnya kubu Jokowi dalam berkampanye tidak ber etika karena menyelipkan iklan untuk memilih Jokowi untuk menjadi presiden di dalam bioskop dan masih banyak sekali permasalahan yang ditujukan pada kedua kubu.

Baru-baru ini terjadi berdepatan hebat antara timses Jokowi dan timses Prabowo sampai-sampai suhu politik di Indonesia semakin memanas, kita bisa melihat pesta demokrasi sebelum-sebelumnya keadaan tenang dan damai. Namun di tahun ini sangatlah dasyat sekali suasananya, karena banyak sekali polemik-polemik yang di hadapi. Saling menghujat dan menghancurkan satu sama lain, tidak ada perdamaian yang tercipta untuk saling mengharagai satu sama lain untuk menjaga persatuan bangsa Indonesia agar tetap bersatu, aman dan damai.

Kalau kita menyikapi untuk kampanye damai apakah hanya jargon atau komitmen? Ditelisik dari hati nurani manusia kita bisa melihat mana yang membuat suatu permasalahan akan baik-baik saja atau sebaliknya semua akan berdampak tidak baik bagi kita sendiri maupun orang lain. Setiap orang memiliki hati nurani yang asalnya dari Tuhan untuk dapat bertindak dengan baik. Seharusnya timses Jokowi dan timses Probowo berfikir dengan lebih positif lagi untuk membangun bangsa Indonesia lebih baik lagi, bergandeng tangan bersatu untuk saling bekerjasama membangun bangsa demi rakyat. Bukan seperti ini, semakin 
mempengkeruh suasana dan membuat masyarakat semakin bingung akan memilih siapa untuk masa depan bangsa Indonesia.

Dunia politik memang hari-hari ini menjadi sorotan, karena banyak acara televisi yang menayangkan perdebatan para petinggi negri yang tergabung dalam timses Jokowi dan timses Prabowo, semua saling menyalahkan dan mencari selah-selah yang dianggap mereka itu benar. Secara hati nurani yang asalnya itu dari Tuhan kita sebagai manusia harus saling mengisi kekosongan satu sama lain, bergerak bersama untuk kepentingan bersama untuk menjujung tinggi persaudaraan yang lebih erat untuk tujuan bangsa Indonesia yang lebih maju dan berkembang. Tidak seperting petinggi-petinggi negri kita ini saling mencemooh dan saling menghujat satu sama lain demi kepentingan pribadi.

Banyaknya berita hoaks yang beredar di masyarakat juga membuat semakin panasnya suhu politik di Indonesia, semakin banyak pembahasan untuk di debatkan para petinggi untuk membela diri dan meyakini bahwa pilihannya itu benar. Benyak deklarasi para timses yang menggulkan dukungannya masing-masing, dari pembahasan tentang ekonomi, kesejahteraan sanpai bagaimana pemerintah menangani kaum muda-mudi untuk terus maju dan berkembang dalam berfikir untuk kemajuan bangsa dan negara.

Dengan hati nurani yang baik pasti akan menghasilkan pemikiran yang baik juga untuk berfikir cerdas dan optimis mana yang menjadi terbaik untuk mengatur bangsa dan negara Indonesia ini kedepannya. Petinggi-petinggi negri boleh memperdebatkan apa yang yang mereka nilai memang sepantasnya untuk di dibicarakan dan di bahas dengan sangat detailnya.

Media televisi maupun media komunikasi online lainnya yang memuat berdepatan antara dua kubu ini hanya menjadikan referensi bagi masyarakat untuk berfikir lebih cerdas lagi dalam memilih demi masa depan bangsa Indonesia yang besar ini. Pemimpin yang baik adalah pemimpin yang mampu memberikan dan melakukan apa yang di inginkan masyarakat, dan untuk para petinggi negri seharusnya mampu menjernihkan suasana agar kampanye antara dua kubu ini baik-baik saja aman dan damai, agar suara rakyat benar-benar di dengarkan dan di lakukan dengan maksimal demi perubahan bangsa Indonesia yang lebih baik lagi. 


\section{BAB III}

\section{KESIMPULAN DAN SARAN}

\section{A. KESIMPULAN}

Dalam pembahasan ini kita bebicara tentang kampanye damai yang di galakkan, namun masih banyak para petinggi-petinggi negri yang berusaha mendeklarasikan gagasannya sesuai dengan apa yang mereka lihat dengan data-data yang mereka cari sesuai dengan kenyataannya. Petinggi-petinggi boleh mendebatkan apa yang mereka ingin sampaikan untuk kesuksesan pesta kampanye yang terjadi, karena itu hak mereka sabagai timses. Apapun yang mereka lakukan untuk kepentingan partai dan timses calon presiden dan wakil presiden selama itu masih dapat menjaga stabilitas keaaman dalam negri. Apapunyang mereka utarakan dan sampaikan itu hak mereka untuk menyampaikan sebagai juru bicara kampanye untuk kepentingan sebagai timses. Karena papun yang terbaik dan terpilih untuk menjadi pemimpin bangsa negara Indonesia semuanya di tangan masyarakat Indonesia.

\section{B. SARAN}

Sebagai masyarakat yang baik kita harus menjadi rakyat yang peka dan mawas untuk negara ini tetap aman dan damai dalam pesta demokrasi ini. Dan sebagai petinggipetinggi negara seharusnya dapat menjadi contoh yang baik bagi masyarakat untuk bersimpatik dengan baik di pesta demokrasi saat ini. Karena negara dan bangsa yang baik akan terus belajar menghargai setiap keputusan yang telah di tetapkan. 


\section{DAFTAR PUSTAKA}

Dewantara.A.W. 2007; Filsafat Moral. PT Kanisius.Depok

Dewantara, A. Kasus Loli Candy’s Ditinjau Dari Etika Dan Teori Hati Nurani.

Rahayu, A., \& Dewantara, A. (2018). STUDI KASUS EKSEKUSI MATI TKI INDONESIA (TUTI TURSILAWATI) DITINJAU DARI TEORI TINDAKAN MANUSIA, TATANAN MORAL SUBJEKTIF, DAN TATANAN MORAL OBJEKTIF.

Rahayu, A., \& Dewantara, A. (2018). STUDI KASUS EKSEKUSI MATI TKI INDONESIA (TUTI TURSILAWATI) DITINJAU DARI TEORI TINDAKAN MANUSIA, TATANAN MORAL SUBJEKTIF, DAN TATANAN MORAL OBJEKTIF. 